\title{
EE
}

PAPER - OPEN ACCESS

\section{Arsitektur Vernakular Berdasarkan Aspek Sosial-Budaya Pada Ruko Di Kota Medan}

\author{
Author : Imam Faisal Pane dkk., \\ DOI $\quad: 10.32734 /$ ee.v3i1.846 \\ Electronic ISSN $\quad: 2654-704 X$ \\ Print ISSN : :2654-7031
}

Volume 3 Issue 1 - 2020 TALENTA Conference Series: Energy \& Engineering (EE)

This work is licensed under a Creative Commons Attribution-NoDerivatives 4.0 International License.

Published under licence by TALENTA Publisher, Universitas Sumatera Utara 


\title{
Arsitektur Vernakular Berdasarkan Aspek Sosial-Budaya Pada Ruko Di Kota Medan \\ Vernacular Architecture Based on Socio-Cultural Aspects of Shophouses in Medan City
}

\author{
Imam Faisal Pane ${ }^{\mathrm{a}}$, Nila Rahmaini Siregar ${ }^{\mathrm{a}, *}$, Rizki Namira Lubis ${ }^{\mathrm{a}}$ \\ ${ }^{a}$ Departemen Arsitektur, Universitas SumateraUtara, Medan 2015, Indonesia
}

Imam.faisal@usu.ac.id,nilasrg@gmail.com,namirarizki@yahoo.com

\begin{abstract}
Abstrak
Arsitektur vernakular merupakan arsitektur yang terlahir dari masyarakat sebagai cerminan tradisi lokal dan terus berkembang dikarenakan sifatnya yang fleksibel dengan potensi sekitarnya. Salah satu bentuk arsitektur vernakular yang muncul di Kota Medan adalah ruko sebagai hasil pengembangan arsitektur vernakular dalam konteks perkotaan yang mana masyarakatnya berasal dari daerah rural dan memiliki latar belakang yang berbeda-beda sebagai hasil akibat dari akulturasi sehingga mempengaruhi identitas dari dearah tesebut melalui perubahan ataupun penyesuain karakter arsitektur yang menampilkan ciri khas. Ruko digunakan mayoritas masyarakat di Kota Medan sebagai tempat tinggal dan juga berwira usaha. Tujuan dari penelitian ini adalah untuk medapatkan hubungan komprehensif antara arsitektur vernakular dan ruko. Metode Penelitian yang digunakan dalam penelitian ini adalah deskriptif analitis yang dalam pelaksanaanya dilakukan proses pengumpulan data, menganalisis data, dan menafsirkannya berdasarkan aspek sosialbudaya. Dari data yang didapat dihasilkan adanya hubungan antara arsitektur vernakular dan bangunan ruko.
\end{abstract}

Kata kunci: Arsitektur Vernakular, Perkembangan Arsitektur Vernakular, Urban Architecture, Ruko, Aspek Sosial-Budaya ;

\begin{abstract}
The vernacular architecture was born from the community as a reflection of local traditions and continues to develop due to its flexibility with its surrounding potential. One form of vernacular architecture that arises in Medan City is shophouses as a result of the development of vernacular architecture in an urban context where the people come from rural areas and have different backgrounds as a result of acculturation that affects the identity of the region through changes or adjustments. Architectural characters that display characteristics. Shophouses are used by the majority of people in Medan as a place to live and also do business. The purpose of this study is to obtain a comprehensive relationship between vernacular architecture and shophouses. The research method used in this research is analytical descriptive in which the data collection process is being collected, analyzing the data, and interpreting it based on socio-cultural aspects, from the data obtained produced a relationship between vernacular architecture and shophouses.
\end{abstract}

Keywords: Vernacular Architecture, Vernacular Architecture Development, Urban Architecture, Shophouse, Socio-Cultural Aspects;

\section{Pendahuluan}

Arsitektur vernakular umumnya dianggap sebagai rumah tradisional yang dibangun dari cerminan budaya dan tradisi masyarakat yang sudah melalui proses 'trial and error' [1][2]. Arsitektur vernakular dapat dikatakan sebagai arsitektur yang lahir dan tumbuh dari rakyat dan dikembangkan oleh masyarakat melalui pendekatan arsitektural dan berakal pada 
tradisi setempat [3]. Disamping itu, arsitektur vernakular dipicu oleh dampak dari kemajuan teknologi dan tuntutan sosial-budaya yang menjadikan arsitektur vernakular dapat beradaptasi dengan lingkungan di sekitarnya [3].

Di Indonesia sendiri, tingginya tingkat urbanisasi dan imigrasi di masa penjajahan menyebabkan jalinan hubungan interkultural antar budaya yang menciptakan proses akulturasi dimana hubungan ini secara langsung atau tidak langsung menumbuhkan suatu perdaban baru yang akan membawa gaya dan tatanan yang baru [5]. Medan sendiri tidak lepas dari citra ruko sebagai bangunan wajib wajah di Kota Medan.

Perkembangan ruko secara keseluruhan di Indonesia bermula dari kota-kota besar kian sudah menjamur di Kota Medan sebagai sebuah subjek dalam proses pencarian jati diri budaya arsitektur vernakular. Ruko menjadi pilihan mayoritas masyarakat Kota Medan karena memiliki fleksbilitas yang tinggi yakni mencakup bangunan komersial dan hunian juga [6]. Namun, keberadaan kehidupan di dalam ruko telah banyak memberikan hal penting mengenai budaya bermukim perkotaan lewat konsep-konsep dan teknologi rumah tangga. Walaupun seiring dengan perkembangan zaman, perkembangan tipologi ruko tidak begitu saja terhenti karena hampir di seluruh kota Medan, baik ruko lama maupun ruko baru yang masih dibangun masih memenuhi daerah-daerah padat komersial, baik di dalam wilayah pecinan maupun di luar. Namun, seiring dengan pertumbuhan ekonomi yang pesat, konsep ruko semakin lama semakin modern karena sudah mulai memanfaatkan potensi dari lingkungan yang lebih luas.

Elemen-elemen pembentuk identitas kawasan hilang sehingga identitas pada pada bangunan ruko juga hilang dan ruko hanya memperkuat posisinya sebagai bangunan komersial. Lambat laun fungsi hunian tidak lagi dapat diakomodasi karena kondisi lingkungan yang tidak mendukung dan persepsi yang berubah. Dapat dikatakan juga bahwa ruko-ruko ini dengan sendirinya juga mengabaikan konsep-konsep tradisional yang dulu vital bagi sebuah hunian dan kehilangan kualitas karena banyak yang menggunakannya bukan lagi sebagai tempat tinggal tetapi lebih diperuntukkan sebagai bangunan komersial yang fleksibel, mudah dibangun, dan harganya terjangkau. hasilnya adalah tipologi ruko yang terlalu monoton tersebar di berbagai pelosok kota sehingga menggeser fungsi-fungsi hunian ke pinggiran kota [7].

\section{Arsiterktur Vernakular}

Kata vernakular menurut Nuttgents (2013) dalam bukunya "The Nature of Architecture" diterjemahkan sebagai home-born slave atau "budak pribumi", dengan kata lain diartikan sebagai budak yang berasal dari dalam negeri dimana istilah vernakular ini digunakan untuk mendeskripsikan kebudayaan masyarakat etnik berdasarkan pertimbangan waktu dan tempat. Kebudayaan dimaksud adalah kebudayaan asli terlahir dari kondisi masyaraktnya yang masih sederhana, merujuk pada produk dari karya masyarakat serta dibawa turun temurun diantaranya berupa arsitektur [8]. Arsitektur dalam konteks vernakular memberikan ciri akan sebuah desain bangunan [9], dimana keduanya memiliki hubungan yang mengacu kepada 'tempat tinggal' dari masyarakat etnik sebagai cerminan tradisi selama kurun waktu tertentu [8] dan menjadi sebuah karakteristik bentukan bangunan yang memiliki tingkatan korelasi filosofi nan kuat, juga sebagai wujud apresiasi terhadap nilai setempat baik identitas suatu budaya [10][11].

Secara umum arsitektur vernakular merupakan cerminan tradisi lokal yang tumbuh dan berkembang berdasarkan kebutuhan masyarakat dimana ketersediaan material saat itu bersembumber dari seadanya, dan sebagai jawaban atas pengaruh lingkungan tempat tersebut berada [12][13]. Hal ini menjadikan arsitektur vernakular tidak kalah saing dengan aliran arsitektur lainnya sebab selain dibangun berdasarkan tradisi juga memanfaatkan potensi lokal yang ada, dan mampu untuk beradaptasi dengan kondisi fisik, sosio-kultur dan lingkungannya[14]. Arsitektur vernakular berkoherensi pada ornamen, ruang, bentukan material dan aturan yang mana koherensi itu muncul sebagai akibat terbentuknya sebuah kesepakatan dan persetujuan masyarakat lokal, kesepakatan ini terjadi melalui proses pengakuan, menciptakan sebuah prinsip hidup yang dikenal sebagai tradisi setempat [15].

Arsitektur vernakular memiliki kaitan erat dengan bangunan lokal atau arsitektur tradisional. Arsitektur tradisional kerap dijadikan sebuah simbol budaya suatu kawasan dikarenakan maknanya yang orisinil berupa simbolik bagi masyarakat yang bersangkutan dan hanya ditemui di wilayah tertentu saja [16]. Hubungan ini menjadi landasan mengapa arsitektur tradisional sering dikaitkan dengan arsitektur vernakular. Di Indonesia, arsitektur vernakular terlahir dari suaru kawasan dimana masyarakatnya mempunyai ikatan yang kuat dengan adat dan tradisi agar dapat beradaptasi dengan 
lingkungan sekitarnya sehingga melahirkan sebuah adat dan tradisi [17]. Sebagai hasilnya terbentuk sebuah kepribadian dan identitas yang mengharapkan agar masyarakatnya dapat bertindak sesuai dengan norma-norma yang sudah ditanamkan oleh leluhur berdasarkan kondisi lingkungan dan arsitektur yang melahirkan arsitektur rakyat dimana menurut Oliver (2006) dalam "Dwellings: The Vrenacular House Worldwide" sebagai bentuk respon terhadap kebutuhan dasar suatu komunitas masyarakat, ekonomi dan tatanan hidup masyarakat.

Akhirnya perkembangan arsitektur mengalami suatu tahap dimana dalam peruntukannya disesuaikan dengan kebutuhan penghuninya. Aspek fungsi dalam arsitektur vernakular sangat diperhatikan, tidak mengedepankan estetika ataupun kehadiran langgam/gaya pada bangunan hanya sedikit perannya [18]. Namun tekanan pada saat masa penjajahan di bidang perekonomian dan pertumbuhan penduduk yang pesat berimbas terhadap perubahan dari sisi arsitektur vernakular yang terus menyesuaikan diri dengan lingkungannya, sehingga memberikan dampak lain pada segi potensi, ekonomi, serta budayanya [3]. Penyesuain ini tentunya akan merubah kebutuhan terhadap bangunan yang terjadi dalam kurun waktu tertentu akibat proses adaptasi untuk dapat memenuhi kebutuhan generasi kedepannya yang akhirnya merujuk kepada konteks setempat (lokal) yang dirancang berdasarkan aspek fungsi [19]. Walaupun demikian, arsitektur vernakular tidak kehilangan identitasnya sebagai prasasti dari peradaban yang dibawa turun temurun, arsitektur vernakular tidak bergerak dengan sendirinya melainkan berasal dari hasil pemikiran masyarakatnya sendiri yang mencoba untuk tetap dapat bertahan.

Arsitektur vernakular tidak hanya terlahir diwilayah pedalaman yang memiliki nilai kearifan lokal yang tinggi, melainkan juga dapat berkembang di wilayah perkotaan atau disebut sebagai urban vernacular yaitu vernakularisme dalam setting perkotaan [20] yang umumnya ditemukan di negara berkembang.

Vernakular dalam konteks arsitektur perkotaan sendiri baik dalam bentuk pengimplemetasinya diartikan sebagai suatu upaya dalam mencari identitas dengan mencerminkan keadaan sosial sekarang dan nantinya [21] yang mana arsitektur vernakular yang terbentuk pada sebuah komunitas pedalaman (rural), hendaknya dilakukan penyesuaian karakter arsitektur sebelum diterapkan dalam perkotaan (urban) [21]. Fenomena urban vernakular juga timbul akibat pertambahan penduduk yang berangsur angsur dan konsekuensi sosial sehingga menciptakan suatu bentuk baru dari peradaban yang berkembang dan menjadi solusi baru dari bentukan vernakular [22]. Kebutuhan dalam keberlangsungan hidup mendorong masyarakat ini untuk dapat menumakan inovasi sendiri berdasarkan latar belakang budaya mereka masingmasing. Solusi ini sering datang sebagai wujud respon terhadap kebutuhan hidup yang semakin menipis.

\section{Arsirektur Vernakular sebagai Identitas Lokal}

Perkembangan jaman menjadi pengaruh terbesar dalam pertumbuhan dan perkembangan arsitektur [23]. Identitas merupakan sebuah peninggalan peradaban yang berkembang sesuai dengan zamannya dan terjadi tidak dengan sendirinya melainkan muncul akibat kondisi di sekitarnya [3].Identitas ini menjadi dasar dari sebuah kearifan lokal (local wisdom) dimana kearifan lokal budaya menjadi faktor utama dalam mendifiniskian identifikasi karena keterkaitan masyarakat terhadap budaya yang terbentuk. Budaya sendiri memiliki hubungan yang kuat dengan tempat atau lingkungan alami yang mana diartikan sebagai suatu hubungan kompleks anatar iklim, biologi, geologi dan topografi yang menciptakan perbedaan di sekitar [24].

Dalam arsitektur, identitas tidak dapat dipisahkan antara fitur dan karakter sebuah bangunan. Identitas akan menjadi indikator dimana bangunan didirikan dan oleh siapa bangunan tersebut digunakan[23]. Identitas mempunyai korelasi dengan topografi, budaya dan arsitek yang menangani. Suatu wilayah dikatakan memiliki jati diri apabila memiliki identitas yang membedakannya dengan yang lain [25].

Vernakular sebagai tolak ukur suatu kawasan yang dikatakan memiliki sebuah identitas. Seiring dengan perkembangan suatu wilayah tentunya, pertambahan penduduk akan meningkat sehingga menyebabkan terjadinya akulturasi atau proses jalinan hubungan interkultural yang secara langsung atau tidak langsung menumbuhkan suatu peradaban baru [26] hingga akhirnya telahir akulturasi desain [27]. Definisi dari arsitektur akulturasi ini sendiri merupakan wujud pencampuran dari cerminan masing-masing budya tanpa menghilangkan ciri khas budayanya. 
Menurut Gülmez (2007) aspek budaya dan ekologi merupakan dua buah entitas yang saling melengkapi. Dalam konteks budaya, identitas sebuah kota merupakan nilai-nilai tradisi dan budaya yang direfleksikan oleh arsitektur berkelanjutan (sustainability architecture). Sementara dalam konteks ekologi, adaptasi kearifan lokal dan arsitektur vernakular merupakan sesuatu yang dapat dihasilkan oleh arsitektur berkelanjutan sebagai solusi terhadap kondisi dan lingkungan. Sementara arsitektur vernakular yang mewarisi kearifan lokal merupakan dua esensi dari nilai-nilai keberlanjutan (sustainability) yang dapat mengatasi permasalahan lingkungan dan mencerminkan nilai-nilai budaya yang tinggi, dilihat dari karakter bangunannya. Menurut James Ackerman dalam artikelnya "The History of Design and The Design of History", dalam menciptakan suatu pengalaman terhadap suatu lokasi sebaiknya sasaran perancangan suatu bangunan dan kotanya harus menciptakan korelasi antara sosial dan pertimbangan ekologi.

\section{Ruko sebagai Hunian}

Dalam kajian, arsitektur merupakan hasil kebudayaan dari masyarakat dimana kedua hubungan ini saling berkaitan satu sama lain dikarenakan masyarakat dalam berkehidupan sosial tidak dapat dilepaskan dengan kebudayaan [28]. Medan merupakan kota metropolitan ketiga setelah Jakarta dan Surabaya, menjadikan Medan sebagai kota multientis dimana penduduknya berasal dari latar belakang yang berbeda-beda. Etnis Melayu dan Karo dikenal sebagai etnis pendahulu yang mendiami kota Medan lalu disusul oleh etnis Jawa, Batak, Mandailing, dan Tionghoa. Beberapa etnis tersebut membawa tradisinya ke kota Medan seperti Tionghoa yang banyak memilih ruko sebagai fungsi hunian dan berdagang [29]. Penggunaan ruko juga tidak dibatasi oleh masyarakat Tionghoa saja bahkan masyarakat lainnya marak menjadikan ruko sebagai sarana alternatif dalam memilih tempat usaha dan hunian sekaligus.

Pengertian ruko atau sering dikenal sebgaai "rumah toko" merupakan hunian fungsi ganda yang terdiri dari 2-5 lantai, dimana lantai terbawah digunakan sebagai tempat berjualan (toko) dan lantai atas sebagai tempat hunian. Konsep ruko sebagai hunian dan juga tempat usaha biasanya digunakan oleh masyarakat kalangan menengah kebawah, hal ini dikarenakan sebagai wujud tindakan akan kebutuhan yang mendesak dalam meningkatkan taraf kehidupan ekonomi penghuni ruko [30].

\section{Metodologi}

Metode penelitian yang digunakan adalah metode deskriptif analisis. Teknik pengumpulan data yang digunakan adalah wawancara, observasi langsung ke kawasan penelitian dan mengumpulkan data-data yang terkait dengan pembahasan penelitian. Berdasarkan hasil telaah teori, untuk menemukan keterkaitan anatara arsitektur vernakular dengan ruko maka digunakanlah salah satu aspek pembentuk vernakular yaitu aspek sosial-budaya. Hasil yang didapatkan dari lapangan akan di korelasikan dengan teori arsitektur vernakular berupa aspek sosial-budaya pada ruko.

Berdasarkan penelitian arsitektur vernakular pada ruko maka dipilih tiga sampel ruko yang mengwakili populasi ruko di Kota Medan diantaranya adalah Ruko Kesawan, Ruko Mandala, dan Ruko Setia Budi. Pemilihan ruko ini berdasarkan usia ruko dan tingkat kepadatan ruko di kawasan.

\section{Hasil dan Pembahasan}

\subsection{Aspek Sosial Budaya terhadap ruko di Kota Medan}

Budaya merupakan media penghubung antara lingkungan binaan melalui ekspresi budaya yang berada didalamnya [14]. Ruko di Medan menjadi contoh bentuk dari sebuah budaya. Hal ini dapat dilihat dari ruko tua yang berada di daerah Kesawan yang dulunya dibangun demi kepentingan perdagangan untuk masyarakat Tionghoa. Terlihat kekentalan budaya pada ruko tersebut khususnya pada fasad dimana terjadi pencampuran antara budaya Melayu, Cina, dan Kolonial sebagai akibat dari akulturasi [31].

Seiring bertambahnya jumlah penduduk, kebutuhan akan lahan tentunya meningkat, ruko mulai menjadi pilihan alternatif untuk bertempat tinggal dan berwira usaha [32]. Perkembangan ruko mulai terfokus pada fungsinya sebagai 
bangunan komersial dan mulai meninggalkan penggunaan ornamen ruko pecinaan pada bentukan bangunan ruko. Namun ruko masih menggunakan bentuk arcade, struktur bangunnanya yang bertingkat dan juga pola ruangnya yang terus mengikuti pola banguan ruko tua. Arsiktur vernakular juga tidak hanya dilihat dari fisik bangunannya saja melainkan juga bentukan pada pola-pola pembentuk bangunan yang terus menerus diikuti sejak dahulu [14] seperti yang dirincikan pada Tabel 1.

\subsection{Ruko Kesawan}

Bentukan pada ruko Kesawan ini didasari oleh pengaruh budaya yang bertempat di lingkungan dan terlahir sebagai hasil dari akulturasi. Bagian interior dari bangunan kental dengan budaya China (Gambar 6.1) hal ini dapat dilihat (observasi) dari ruangan yang digunakan sebagai tempat sembahyang. Sedangkan pada bagian eksterior dari bangunan khususnya jendela dan ornamen lainnya kental dengan budaya Melayu dan Kolonial berdasarkan pola perulangan yang digunakan pada fasad bangunan

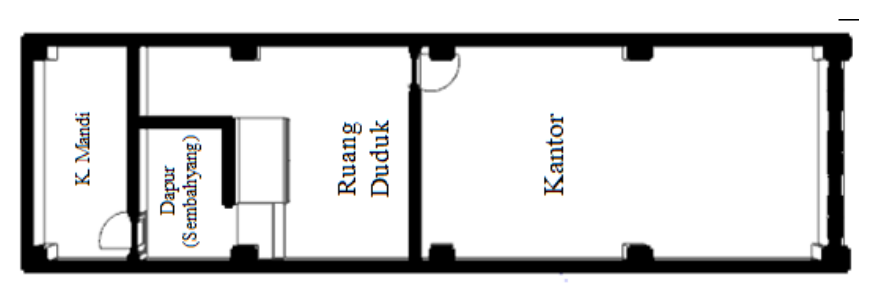

Gambar 6.1Ineterior ruko yang kental akan budaya China

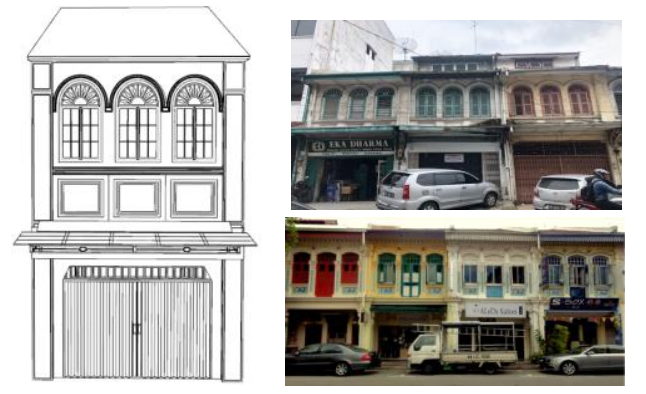

Gambar 6.2Eksterior ruko yang kental akan budaya Kolonial dan Melayu

\subsection{Ruko Mandala}

Kawasan Mandala murni digunakan sebagai tempat strategis untuk berjualan hal ini dapat dilihat dari sekeliling kawasan yang padat akan ruko. Jika dilihat bentukan ruko secara keseluruhan maka tak akan terlihat pengaruh budaya yang signifikan di dalamnya. Namun pemilik mempercayai adanya pengaruh filosofi Cina yang cukup kuat dalam membentuk ruko pada umumnya dimana jika pintu ruko yang lebar dan penghilangan sekat akan memberikan dampak yang positif dalam berwirausaha seperti usaha yang lancar (Gambar 6.3). Penggunaan pola bentukan ruko juga masih digunakan terutama masih menggunakan fungsi sebagai bangunan hunian dan juga tempat usaha (Gambar 6.4).

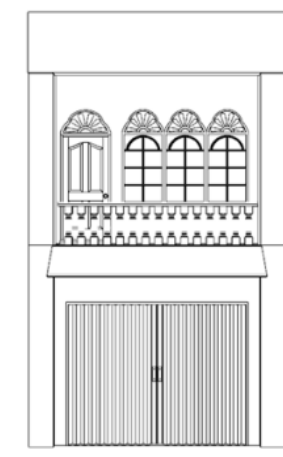

Gambar 6.3Bentukan pintu yang lebar memberi dampak positif
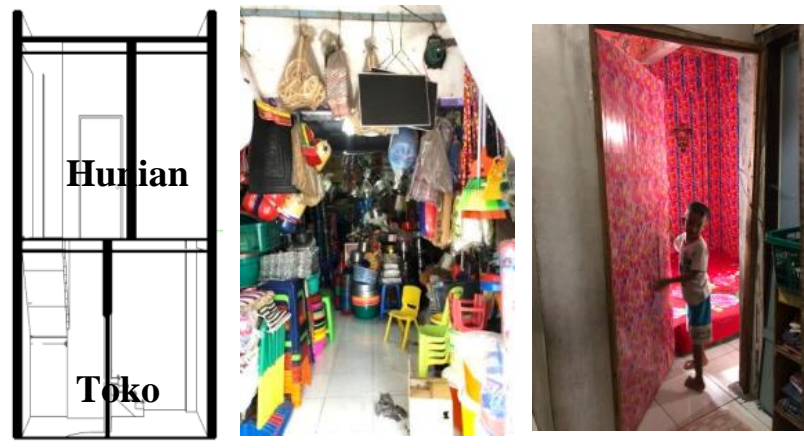

Gambar 6.4 Fungsi hunian dan tempat berdagang

\subsection{Ruko Setia Budi}

Mayoritas ruko yang berada di kawasan Setia Budi termasuk ke dalam kategori ruko baru, dalam arti ruko modern yang bangunannya sudah tidak menganut gaya ruko pecinan dan penggunaan ornamen hanya sebatas estetika saja. Ruko pada kawasan ini banyak dimanfaatkan sebagai tempat komersil, walaupun sudah tidak tampak lagi pengaruh budaya 
yang signifikan pada ruko. Namun ruko tetap menggunakan pola-pola bentukan ruko yang terus diikuti yaitu fasadnya yang berebentuk arcade (gambar 6.5) dan strukturnya yang grid (Gambar 6.6).

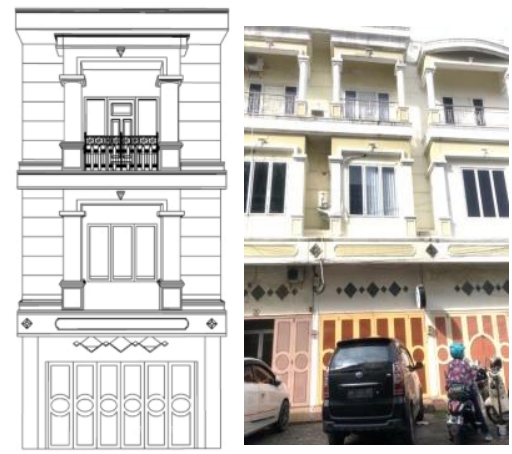

Gambar 6.5Bentuk fasad Arcade

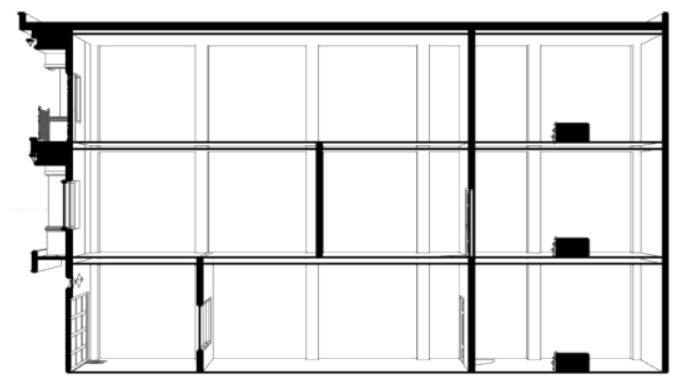

Gambar 6.6Bentuk struktur Grid

Tabel 1. Tabel hasil

\begin{tabular}{|c|c|c|}
\hline No & Kawasan & Aspek Sosial Budaya \\
\hline 1 & Ruko Kesawan & $\begin{array}{l}\text { Terlahir sebagai hasil dari akulturasi masyarakat setempat terdahulu } \\
\text { sehingga bangunan ruko kental akan ciri khas dari masing-masing } \\
\text { budaya }\end{array}$ \\
\hline 2 & Ruko Mandala & $\begin{array}{l}\text { Masyarakat sudah mulai mengurangi penggunaan ornamen pada } \\
\text { bangunan ruko dan mengutamakan fungsi dikarenakan masyarakat } \\
\text { yang menggunakan ruko tidak lagi terbatas penggunaannya oleh suku } \\
\text { tertentu }\end{array}$ \\
\hline 3 & Ruko Setia Budi & $\begin{array}{l}\text { Ruko lebih mementingkan fungsi dan penggunaan ornamen yang } \\
\text { terdapat dalam ruko hanya sebagai estetika saja. Namun, bentukan dari } \\
\text { ruko baru ini terus mengikuti bentukan dari bentuk ruko lama seperti } \\
\text { Kesawan dan Mandala sebagai bentukan arsitektur vernakular }\end{array}$ \\
\hline
\end{tabular}

\section{Kesimpulan}

Arsitektur vernakular merupakan proses sekaligus sebuah hasil karya manusia sebagai upaya pemberian makna terhadap lingkungannya. Selain itu, arsitektur vernakular bersifat progresif dan kontekstual karena berkembang dalam menjawab tantangan dan kondisi terkini, serta serasi atau selaras dengan cara berpikir manusia. Salah satu bentuk arsitektur vernakular yang muncul di Kota Medan adalah ruko. Ruko di Kota Medan terlahir sebagai hasil pengembangan arsitektur vernakular dalam konteks perkotaan dimana masyarakatnya memiliki latar belakang yang berbeda-beda sebagai hasil dari proses akulturasi [33]. Masyarakat Medan umumnya berasal dari daerah rural yang mencoba untuk dapat berdaptasi dalam lingkup kehidupan perkotaan dengan membawa budaya asalnya dan memanfaatkan potensi di sekitarnya [22]. Ruko sendiri digunakan masyarakat Medan yang mayoritas berdagang sebagai tempat hunian dan sekaligus mencakup tempat usaha. Perkembangan ruko kian meningkat hal ini dikarenakan pertumbuhan masyarakat yang tinggi dan lahan sempit. Masyarakat mulai terfokus pada pemanfaatan lahan ataupun fungsi dari ruko tersebut [34]. Ditinjau berdasarkan aspek sosial-budaya yang merupakan aspek pembentuk vernakular bahwa arsitektur vernakular pada ruko terbentuk dari proses akulturasi dimana dahulunya ruko di Kota Medan kental akan ornamen pecinaannya namun mulai berubah dikarenakan masyarakat yang menempati ruko sekarang bukan hanya masyarakat Tionghoa saja namun juga masyarakat dari berbagai kalangan. Akibatnya, ornamen ruko pecinaan dari 
akulturasi terdahulu mulai menghilang dan diganti dengan akulturasi masyarakat kini yang lebih mementingkan fungsi dikarenakan pencampuran-pencampuran masyarakat dari asal-muasal yang berbeda. Walaupun demikian arsitektur vernakular tidak hanya dilihat dari bentukan fisik bangunannya saja melainkan juga dari penggunaan pola-pola pembentuk ruko hingga sekarang.

\section{Ucapan Terima Kasih}

Ucapan terima kasih penulis sampaikan kepada Universitas Sumatera Utara Fakultas Teknik Departemen Arsitektur dan Seminar Nasional Kearifan Lokal 5 yang sudah memberikan kesempatan untuk menjadi lembaga yang membantu pelaksanaan penelitian ini. Ucapatan terimakasih juga disampaikan kepada semua pihak yang terlibat dalam membantu penelitian ini

\section{Referensi}

[1] Turan, Mete (2007) : Vernacular Architecture: Paradigms of Environmental Respose, Avebury Studies in Green Research, Vol. 4

[2] Arfianti, Ami, Prijotomo, Josef, dan, Setijanti, Purwanita (2017) : Arsitektur Vernakular: Penelusuran Pengaruh Tradisi atas Lingkung Bina, Prosiding Seminar Heritage IPLBI, E-ISBN:978-602-17090-4-7

[3] Wiranto (1999) : Arsitektur Vernakular Indonesia: Perannya dalam Pengembangan Jati Diri, Dimensi Teknik Arsitektur, Vol. 27, 15-20

[4] Bosman, G., Whitfield, C. (2015) : Preceptions of Vernacular Architecture, Vernacular Architecture: Towards a Sustainable Future, ISBN: 978-1$138-02682-7$

[5] Berry, Jhon W. (2005) : Acculturation: Living Succesfully in two cultures, International Journal Of Intercultural Relations, Vol. 29, 679-712

[6] Harisdani, Devin, dan, Lubis, Muhammad (2004) : Identitas Fungsi Ruko Kesawan, e-USU Repository @2004 Universitas Sumatera Utara

[7] Raubaba, Henry (2014) : Tesis: Kebijakan Publik pada Penyeragaman Fasade Ruko Terhadap Pembentukan Citra Kota Wamena Sebagai Kawasan Perdagangan dan Jasa (Studi Kasus: Koridor Jalan Irian), Program Pasca Sarjana Magister Teknik Arsitektur, Universitas Diponegoro

[8] Suharjanto, Gatot (2011): Membandingkan Istilah Arsitektur Tradisional Versus Arsitektur Vernakular: Studi Kasus Bangunan Minangkabau dan Bangunan Bali,ComTech, Vol.2, 592-602

[9] Rogi, O.H.A. (2011): Arsitektur Vernakular: Patutkah didefinisikan? Jurnal Sabua, Vol. 3, 32-39

[10] Putri, A. Moju. (2017): Konsep Lamin dalam Bangunan Modern dengan Pendekatan Vernakular, Seminar Nasional Seni dan Desain

[11] Prsetya, E.L. (2007): Adaptation and Sustainable Architecture, International Conference of Tropical Architecture within Tradition-Globalization

[12] Carlos, G.D., Correia, M.R., Rocha, S., and Frey P. (2015): Vernacular Architecture?, Seismic Retrofitting:Learning from Vernacular Architecture, 11-16

[13] Rapoport, Amos (2007): House Form and Culture

[14] Mentayani, I., Muthia, P.R. (2017): Menggali Makna Arsitektur Vernakular, Prosiding Temu Ilmiah IPLBI, Vol. 6, 109-116

[15]Salman, Maha (2018): Sustainability and Vernacular Architecture: Rethingking What Identity Is, Urban and Architectural Heritage Conservation within Sustainability

[16] Rogi, O.H.A., Siswanto, W. (2009): Identifikasi Aspek Simbol dan Norma Kultural pada Arsitektur Rumah Tradisional di Minahasa, Ekoton, Vol.9, 44-58

[17]Purbadi, Djarot (2015): Menelusuri dan Memahami Arsitektur Vernakular Nusantara, Seminar Nasional Arsitektur Nusantara

[18] Oliver, P. (2006): Dwellings: The Vernacular House Worldwide, Revised edition, London and New York: Phaidon Press

[19] Suharjanto, G. (2011): Membandingkan Istilah Arsitektur Tradisional versus Arsitektur Vernakular. ComTec, Vol.2, 592-602.

[20] Abioso, W.S. (2011): Memahami “Urban Vernakular" Arsitektur, Majalah Ilmiah UNIKOM, Vol. 9, 147-154.

[21] Firzal, Y. (2018): Konsepsi Vernakular dan Tradisional dalam Konteks Arsitektur Perkotaan, Prosiding Semamyusa (IPLBI), E-ISBN 978-60251605-2-3

[22] Roy, Avik (1988): Tesis: Interpreting a Contemporary Urban Vernacular for Cities: The Case of Delhi, Massachusetts Institute of Technology. Department of Architecture.

[23] Hidayatun, M. I., Prijotomo, J., dan Rachmawati, M. (2014): Arsitektur di Indonesia dalam Perkembangan Jaman, Sebuah Gagasan untuk Jati Diri Arsitektur di Indonesia, Seminar Rumah Tradisional 2014

[24] Mclennan, JF. (2006): The Philosphy of Sustainable Design. Kansas City, MO: EcoTone

[25]Dahliani (2014). Eksistensi Rumah Tradisional Banjar Sebagai Identitas Kawasan Bersejarah di Kelurahan Kuin Utara, Banjarmasin. Modul, Vol. 14 ,

[26] Berry, J.W. (2008): Globalisation and acculturation. International Journal of Intercultural Relations, Vol. 32, 328-336

[27]Prasetya, E.L. (2007): Adaptation and Sustainable Architecture; Manggaraian Traditional Architecture in age of Globalization, International Conference of Tropical Architecture within Tradition-Globalization

[28] Parliana, D., Kasiwi, A., Gumilar, S., Drajati, A., Febian, E., (2018): Kajian Pengaruh Adat Istiadat, Religi, dan Alam Bangunan Adat, Lembah Kuta Ciamis. Jurnal Reka Karsa, Vol. 2. 
[29] Sutrisna, Deni (2007): Ruko dalam Sejarah Arsitektur Kota Perbaungan, Kabupaten Serdang Bedagai, Provinsi Sumetera Utara, Vol. 10

[30] Purwantiasning, Ari (2015): Kajian Tentang Alih Fungsi Hunian Menjadi Tempat Usaha, Jurusan Arsitektur Fakultas Teknik, Universitas Muhammadiyah Jakarta

[31] Karakul, Özlem (2014): Intangible Values of Building Culture in Vernacular Architecture, Vernacular Heritage and Earthen Architecture: Contributions for Sustainable Development, ISBN: 978-1-138-00083-4

[32] Harisdani, Devin, dan, Lubis, Muhammad (2004) : Identitas Fungsi Ruko Kesawan, e-USU Repository @2004 Universitas Sumatera Utara

[33] Roesli, Christianto, Rachmawati, Sri (2014): Akulturasi Arsitektur Kolonial Belanda pada Rumah Toko Cina Peranakan di Jakarta, Humaniora, Vol.5, 228-237

[34] Khatimah, Husnul (2013): Kajian Kesesuaian Pembangunan Ruko terhadap KebutuhanPasar di Kota Mataram, Jurnal Pembangunan Wilayah \& Kota, Vol.9, 271-283 